\title{
Factors Associated with Newborn Asphyxia at Dr. Harjono Hospital, Ponorogo, East Java
}

\author{
Yustina Purwaningsih'), Yulia Lanti Retno Dewi²), Dono Indarto3), Bhisma Murti' \\ ${ }^{1)}$ Masters Program in Public Health, Universitas Sebelas Maret \\ 2)Department of Nutrition, Faculty of Medicine, Universitas sebelas Maret \\ 3)Faculty of Medicine, Universitas sebelas Maret
}

\begin{abstract}
Background: Asphyxia, or perinatal asphyxia, refers to oxygen deprivation during labor or delivery long enough to cause physical harm, and particularly brain damage. When birth asphyxia is severe, it can injure brain cells and cause potentially fatal conditions, including HypoxicIschemic Encephalopathy (HIE), brain injuries, seizures, and cerebral palsy. This study aimed to investigate factors associated with newborn asphyxia at Dr. Harjono Hospital, Ponorogo, East Java. Subjects and Method: This was a case control study conducted at perinatology ward, Dr. Harjono Hospital, Ponorogo, East Java, in July 2018. A sample data of 360 newly born infants between January 2017 and December 2017 was selected for this study by fixed disease sampling, comprising 180 newborns with asphyxia and 180 newborns without asphyxia. The dependent variable was birth asphyxia. The independent variables were low birthweight, prematurity, and post date. The secondary data were obtained from the medical record and analyzed by a multiple logistic regression.

Results: The risk of asphyxia increased with low birthweight $(\mathrm{OR}=4.45 ; 95 \% \mathrm{CI}=2.17$ to 9.10; $\mathrm{p}<0.001)$, prematurity $(\mathrm{OR}=4.83 ; 95 \% \mathrm{CI}=2.41$ to $9.67 ; \mathrm{p}<0.001)$, and post date $(\mathrm{OR}=2.52 ; 95 \%$ $\mathrm{CI}=1.31$ to $4.81 ; \mathrm{p}=0.005)$.
\end{abstract}

Conclusion: The risk of asphyxia increases with low birthweight, prematurity, and post date.

Keywords: asphyxia, neonate, low birthweight, prematurity, post date

\section{Correspondence:}

Yustina Purwaningsihi. Masters Program in Public Health, Universitas Sebelas Maret, Jl. Ir. Sutami No. 36 A, Surakarta 57126, Central Java. Email: yustinapurwaningsih202@gmail.com

\section{BACKGROUND}

According to WHO (2015), infant mortality rate in Indonesia is still much higher than the Association of South East Asia Nations (ASEAN) countries. Indonesia ranked fourth highest after Laos 51 per 1,00o live births, Myanmar 40 per 1,000 live births and Cambodia 25 per 1,00o live births. The results of the Census of Population Interceptor (SUPAS) in 2015 show that infant mortality rate in Indonesia reached $\mathbf{2 2 . 3 3}$ per 1,00o live births (Badan Pusat Statistik, 2015). This figure is much higher compared to Singapore 2 per 1,000 live births and
Malaysia 6 per 1,000 live births (WHO, 2015).

Asphyxia neonatorum is one of the causes of neonatal death worldwide around $24 \%$ of total neonatal death. The demographic survey of asphyxia neonatorum in East Java is at the second place after LBW is 27.38\% (DHO East Java Province, 2013). The results of research in Dr. Harjono hospital Ponorogo in 2010 show that the rate of asphyxia neonatorum is quite high of 19.22\% (Sunarto et al, 2010). The result of preliminary observation at Dr. Harjono hospital Ponorogo from the Medical Record section, show that researchers obtained 
asphyxia neonatorum data in 2016 consisting of 292 babies or $21.8 \%$ asphyxia cases. In 2017 from January - December 15, 2017 there were 259 infants or $15.05 \%$ asphyxia cases.

Asphyxia neonatorum, besides its high prevalence, it also causes later physical and mental developmental abnormalities, such as cerebral palsy, mental retardation, epilepsy and learning disability (Tabassum et al, 2014, Mohan et al, 2013).

Factors causing neonatal asphyxia are: a) pre-natal factors such as: maternal age, pre-eclampsia and eclampsia, socioeconomic, prior birth asphyxia history, b) intra natal factors such as fetal presentation, delivery with cesarean sectio, general anesthesia during cesarean sectio labor, delivery, vacuum extraction, forceps, cord prolapse, cephalo pelvic disproportion (CPD) and premature rupture of membranes, c) Infant factors, including LBW, prematurity, post date, polyhydramnios and Intra Uterine Growth Retardation (IUGR) (Aslam et al, 2014, Tabassum et al, 2014).

LBW is the first cause of asphyxia neonatorum. Serve (2009) states that one of the complications of a baby with LBW is neonatal asphyxia. How easy the baby with LBW has a disorder in the nervous system causes LBW infants at risk of severe asphyxia. Severe asphyxia occurring in LBW also greatly affects the central nervous system, which results from lack of oxygen and lack of tissue perfusion. According to Aslam et al. (2014), LBW is a major cause of neonatal asphyxia and is associated with maternal hypertension and diabetes mellitus during pregnancy and before pregnancy.

Momeni et al. (2017) and Sharma et al. (2015) preterm labor had 22.6 times the risk of LBW and there was a significant relationship with the incidence of
LBW. Premature babies have problems with the respiratory system as well as babies with LBW.

Postdate pregnancy complications also cause placental insufficiency which will result in intrauterine asphyxia. This condition will cause the baby to be born in asphyxia (Adcock et al., 2008).

The purpose of this study is to analyze the factors affecting neonatal asphyxia.

\section{SUBJECTS AND METHOD}

\section{Study Design}

This was an analytic observational study with a case control design. The study was conducted at Dr. Harjono hospital, Ponorogo, East Java.

\section{Population and Samples}

The target population in this study was all infants in Lotus Room, Dr. Harjono hospital, Ponorogo, from January to December 2017. A sample of 360 infants was selected by fixed disease sampling, consisting of 180 infants with asphyxia neonatorum and 180 infants without asphyxia neonatorum.

\section{Study Variables}

The dependent variable was asphyxia neonatorum. The independent variables were LBW, prematurity, and post date.

\section{Operational Definition of Variables}

Asphyxia neonatorum was defined as a condition of infants born with difficulty in breathing with apgar score $<7$ in the first 5 minutes. The result of the measurement was divided into two: a) asphyxia if the value of $A P G A R \leq 6$ in the first 5 minutes with the code " 1 " and b) was not asphyxia if value > of 6 in the first 5 minutes with code "o". The data were taken from medical record. The measurement scale was categorical, coded o for no and 1 for yes.

LBW was defined as an infant born with a birth weight of less than 2500 grams. The data were taken from medical record. The measurement scale was continuous, 
but for the purpose of data analysis, it was transformed into dichotomous, coded o for normal birthweight ( $\geq 22500 \mathrm{~g}$ ) and 1 for LBW $(<2500 \mathrm{~g})$.

The result of measurement from BBLR was divided into 2 ie a) BBLR if the birth weight $<2500$ gram with code " 1 " and b) not BBLR if the birth weight $\geq 2500$ gram with code "o". The data were collected by questionnaire. The measurement scale was categorical.

Premature were defined as infants born with $<37$ weeks gestational age. The measurement results were divided into 2, ie a) premature if $<37$ weeks of pregnancy with code "1" and b) not premature if the gestational age is $\geq 37$ weeks with the code "o". The data were collected by questionnaire. The measurement scale was categorical.

Post date was defined as a baby born with gestational age of more than 42 weeks or close to 42 weeks. The post-date measurement results are divided into 2, ie a) post dete if the baby is born with gestational age $\geq 42$ weeks with the code " 1 " and b) not post date if the baby is born with $<42$ weeks gestation with code "o". The data were collected by questionnaire. The measurement scale was categorical.

\section{Study Instruments}

The data collection technique was done using secondary data. The secondary data were obtained from medical records and baby register books.

\section{Data Analysis}

The data analysis result of research was done using logistic regression with program stata 13 to know relation of the independent variable to the dependent variable.

\section{Research Ethics}

The research ethics include informed consent, anonymity, confidentiality and ethical clearance. The ethical clearance in this study was conducted at Faculty of Medicine, Sebelas Maret University Surakarta and was declared as worthy of ethics based on decision letter number: 113/ UN27.6/ KEPK/ 2018.

\begin{tabular}{l} 
RESULTS \\
\hline 1. Univariate Analysis \\
Table 1 showed that most of the infants had \\
normal birth weight $(245,68.1 \%)$. The \\
number of infants with pre-term birth was \\
$123(34.2 \%)$. The number of infants with \\
post-date was $51(14.2 \%)$.
\end{tabular}

Table 1. The results of univariate analysis

\begin{tabular}{lcc}
\hline \multicolumn{1}{c}{ Variables } & Frequency & (\%) \\
\hline $\begin{array}{l}\text { Neonatorum } \\
\text { Asphyxia }\end{array}$ & & \\
$\begin{array}{l}\text { Asphyxia } \\
\text { Non Asphyxia }\end{array}$ & 180 & 50.0 \\
LBW & 180 & 50.0 \\
LBW & & \\
Non LBW & 115 & 31.9 \\
Prematurity & 245 & 68.1 \\
Premature & & \\
Not Premature & 123 & 34.2 \\
Post Date & 237 & 65.8 \\
Post Date & & \\
Non Post Date & 51 & 14.2 \\
\hline
\end{tabular}

\section{Bivariate Analysis}

The data were analyzed by Chi-square to observe the association between LBW, prematurity, and post date, with asphyxia neonatorum. The results of bivariate analysis can be seen in Table 2.

\section{Multivariate Analysis by Multiple Logistic Regression}

The result of multivariate analysis by a multiple logistic regression was described in Table 3. Table 3 showed that there was a positive association between LBW, prematurity, and post date, on asphyxia neonatorum. 
Table 2. Bivariate Analysis of the Effect of Independent Variables on Neonatorum Asphyxia

\begin{tabular}{|c|c|c|c|c|c|c|c|c|c|}
\hline \multirow{2}{*}{$\begin{array}{c}\text { Independent } \\
\text { Variables }\end{array}$} & \multicolumn{2}{|c|}{$\begin{array}{c}\text { Non } \\
\text { Asphyxia }\end{array}$} & \multicolumn{2}{|c|}{ Asphyxia } & \multicolumn{2}{|c|}{ Total } & \multirow{2}{*}{ OR } & \multirow{2}{*}{$95 \%$ CI } & \multirow{2}{*}{$\mathbf{p}$} \\
\hline & $n=180$ & $\%$ & $n=180$ & $\%$ & $n=360$ & $\%$ & & & \\
\hline \multicolumn{10}{|l|}{ LBW } \\
\hline No & 162 & 66.2 & 83 & 33.8 & 245 & 100 & \multirow[t]{2}{*}{4.45} & 2.17 to & \multirow[t]{2}{*}{$<0.001$} \\
\hline Yes & 18 & $15 \cdot 7$ & 97 & $84 \cdot 3$ & 115 & 100 & & 9.10 & \\
\hline \multicolumn{10}{|l|}{ Prematurity } \\
\hline No & 159 & 67.1 & 78 & 32.9 & 237 & 100 & \multirow[t]{2}{*}{4.83} & 2.41 to & \multirow[t]{2}{*}{$<0.001$} \\
\hline Yes & 21 & 17.1 & 102 & 82.9 & 123 & 100 & & 9.67 & \\
\hline \multicolumn{10}{|l|}{ Post Date } \\
\hline No & 154 & 49.8 & 155 & 50.2 & 309 & 100 & \multirow[t]{2}{*}{2.52} & 1.31 to & \multirow[t]{2}{*}{$<0.005$} \\
\hline Yes & 26 & 51 & 25 & 49 & 51 & 100 & & 4.81 & \\
\hline
\end{tabular}

Table 3. The Result of Multiple Logistic Regression Analysis

\begin{tabular}{lcccc}
\hline \multicolumn{1}{c}{ Asphyxia } & OR & \multicolumn{2}{c}{ 95 \% CI } & p \\
\cline { 3 - 4 } & & Lower limit & Upper limit & \\
\hline LBW & 4.45 & 2.18 & 9.10 & $<0.001$ \\
Prematurity & 4.84 & 2.42 & 9.68 & $<0.001$ \\
Post date & 2.52 & 1.32 & 4.81 & 0.005 \\
\hline
\end{tabular}

Table 3 shows that the risk of neonatorum asphyxia increased with LBW $(\mathrm{OR}=4.45 ; 95 \% \mathrm{CI}=2.17$ to $9.10 ; \mathrm{p}<0.001)$, pre-term birth $(\mathrm{OR}=4.83 ; 95 \% \mathrm{CI}=2.41$ to 9.67; $\mathrm{p}<0001)$, and post date $(\mathrm{OR}=2.52$; $95 \% \mathrm{CI}=1.31$ to $4.81 ; \mathrm{p}=0.005)$.

\section{DISCUSSION}

\section{The relationship between LBW} and neonatorum asphyxia

The result of analysis showed that there was a positive effect between LBW and the incidence of neonatorum asphyxia. LBW increased the risk of neonatorum asphyxia by 4.45 times compared to infants with normal birth weight.

The result of this study was in line with studies by Aslam et al. (2014), Wayessa et al. (2018) which stated that LBW affected the incidence of neonatorum asphyxia. Infants born with LBW have little alveoli and the surfactants that covered the alveoli were also not produced much. Surfactant was a substance that prevent the occurrence of collapse during expiration. Luman small respiratory system, collapse or airway obstruction, and immature lung blood vessels. This condition might interfere the baby's effort to breathe and often result in respiratory distress (Maryunani, 2009).

2. The relationship between preterm labor and neonatorum asphyxia

The result of analysis showed that there was an effect of preterm labor on the incidence of neonatorum asphyxia. Table 3 showed that preterm labor would increase the risk of neonatorum asphyxia by 4.83 times and significantly became the cause of neonatorum asphyxia incidence.

The result of this study was in line with the study by Utomo (2014) and Aslam et al. (2014) which stated that preterm birth affected the incidence of neonatorum asphyxia. Premature babies have an immature lung and their respiratory muscles were also limited as well as LBW infants.

3. The relationship between post date and neonatorum asphyxia

The result of analysis showed that there was an effect of post date on the incidence of neonatorum asphyxia. Table 3 showed 
that post date labor affected the neonatorum asphyxia. Post date labor increased the risk of neonatorum asphyxia by 2.52 times compared to non post date labor and significantly affected the incidence of neonatorum asphyxia.

Manuaba (2009) explained that infants with post dates tend to experience oligohydramnion because infants with post date would aspirate the amniotic fluid. The infant would be an intrauterine asphyxia (fetal distress) and born in a neonatal asphyxia condition. Intrauterine asphyxia would cause the fetus to perform a vagal reflex by removing meconium so that the amniotic fluid would mix with meconium. The fetus in the oxygen deprivation position would make an intra uterine respiratory effort and there might be meconium aspiration. The condition of the fetus who experienced aspiration of meconium would certainly be born in the condition of neonatorum asphyxia.

Factors which affected the incidence of neonatorum asphyxia were LBW, prematurity, and post date. These three factors were significantly associated and might increase the incidence of neonatal asphyxia.

\section{REFERENCES}

Adcock L, Papille L (2008). Perinatal asphyxia, In Cloherty J, Eichenwald Ec, Stark Ar (Ed.) Manual of neonatal care. Philadelphia, Lippincott Williams \& Wilkins. 518-528

Antonucci R, Porcella A, Pilloni MD (2014). Perinatal Asphyxia In The Term Newborn, Journal of Pediatric and Neonatal Individualized Medicine; 3(2): e030269. https://doi:10.7363/ 030269.

Apriyanti F, Fiska Y (2014). Hubungan Paritas Dengan Kejadian Kehamilan Post Date Di RSUD Bangkinang Tahun 2012, Jurnal Kebidanan STIKes
Tuanku Tambusai Riau, ISSN 20880057.

Arief, Kristyanasari W (2009). Neonatus \& Asuhan Keperawatan Anak. Yogyakarta: Nuha Medika.

Arifin J (2008). Statistik Bisnis terapan Dengan Microsoft Exsel 2007, Jakarta, PT Elek Media Kumputindo.

Aslam HM, Saleem S, Afzal R, Iqbal U, Saleem SM, Shaikh MWK, Shahid N (2014). Risk Factors of Birth Asphyxia, Italian Journal of Pediatrics, https://bdoi.org/10.1186/s13052-014-0094-2.

Badan Pusat Statistik (2015). Hasil Penduduk Antar Sensus 2015, Jakarta, Badan Pusat Statistik Indonesia.

Bautista CI, Henriquez SP, Aleman PN, Garcia SJJ, Gonzalez QA. (2013). Maternal Obesity In Early Pregnancy and Risk of Adverse Outcame, PLos ONE (11): e80410, doi:10.1371/journal.pone.0080410.

Behrens I, Basit S, Lykke AJ, Ranthe MF, Wohlfahrt J, Bundgaard $\mathrm{H}$, Melbye M, Boyd HA (2016). Association Between Hypertensive Disorders of Pregnancy and Later Risk of Cardiomyopathy, JAMA 315(10): 1026-1033. doi:10.1001 /jama.2016.1869.

Blomberg M (2011). Maternal obesity and risk of postpartum hemorrhage. Obstet Campbell F, Johnson M, Messina $\mathrm{J}$, et al. Behavioural interventions for weight management in pregnancy: a systematic review of quantitative and qualitative data. BMC Public Health. 11:491.

Chadha IA (2010). Neonatal resuscitation: Current issues, Indian Journal of Anaesthesi, 2010 Sep-Oct; 54(5): 428-438. doi: 10.4103/0019-5049.71042.

Damayanti IP (2014). Asuhan Kebidanan Komperhensif Pada Ibu Bersalin dan 
Bayi Baru Lahir, Yogyakarta, Deepublish.

Daniyati A, Putri P (2012). Analisys Predisposition Factors on Premature Rupture Membranes in Postpartum Mothers, International Conference on Applied Science and Health.

Depkes RI (2009). Asuhan Bayi Baru Lahir Dan Penatalaksanaan Bayi Baru Lahir Dengan Asfiksia, Jakarta: JNPK.

Dinkes Provinsi Jawa Timur (2013). Profil Kesehatan Provinsi Jawa Timur, Surabaya, Dinkes Prov. Jawa Timur.

Duarsa ABS (2008). Prospek Pendidikan Pasca Sarjana Bidang Kesehatan Masyarakat, Jurnal Kesehatan Masyarakat, September 2008-Maret 2009, 3(1).

Dwienda RO (2014). Asuhan Kebidanan Neonatus, Bayi/Balita dan Anak Prasekolah Untuk Para Bidan, Yogyakarta: Deepublish.

Ekwochi U, Asinobi NI, Osuorah CDI, Ndu IK, Ifediora $\mathrm{C}$, Amadi OF, Iheji CC, Orjioke CJG, Okenwa WO and Okeke BI. (2017). Incidence and Predictors of Mortality Among Newborns With Perinatal Asphyxia: A 4-Year Prospective Study of Newborns Delivered in Health Care Facilities in Enugu, South-East Nigeria, Clinical Medicine Insights: Pediatrics, Gynecol. 118(3): 561-8. Doi: 10.1177/1179556517746646.

Fajar (2009). Statistika untuk Praktisi Kesehatan. Yogyakarta: Graha Ilmu Ikatan bidan Indonesia. 2006.

Fitriani, Samad A, Khaeruddin (2014). Penerapan Teknik Pemberian Reinforcement (Penguat) Untuk Meningkatkan Hasil Belajar Fisika Pada Peserta Didik Kelas VIII A SMP PGRI Bajeng Kabupaten Gowa, Jurnal JPF, 2(3), ISSN: 2302-8939, 193.
Flora L, Redjeki IS, Wargahadibrata AH (2014). Perbandingan Efek Anastesi Spinal dengan Anastesi Umum terhadap Kejadian Hipotensi dan Nilai APGAR Bayi pada Seksio Sesarea, Jurnal Anastesi Perioperatif, 2(2).

Gunawan (2010). Manajemen Pemasaran Analisis Untuk Perencanaan Strategi Pemasaran, Yogyakarta, UPP STIM YKPN.

Hakimi M (2010). Ilmu Kebidanan Patologi dan Fisiologi Persalinan, Yogyakarta: Yayasan Essentia Medica (YEM).

Hidayat AAA (2008). Pengantar Ilmu Kesehatan Anak Untuk Pendidikan Bidan, Jakarta, Salemba Medika.

Ilah BG, Aminu MS, Musa A, Adelakun MB, Adeniji AO, Kolawole T (2015). Prevalence and Risk Factors for Perinatal Asphyxia as Seen at a Specialist Hospital in Gusau, Nigeria. Sub-Saharan Afr J Med. 2:64-9. Doi: 10.4103/2384-5147.157421

Intarti WD, Puspitasari L, Pradani RI (2016). Efektifitas Muscle Pumping dalam Meningkatkan Score APGAR pada Bayi Baru Lahir degan Asfiksia, Jurnal Kebidanan, 8(1).

Jebessa Wayessa Z, Belachew T, Joseph J (2018). Birth asphyxia and associated factors among newborns delivered in Jimma zone public hospitals, Southwest Ethiopia: A cross - sectional study, Journal of Midwifery and Reproductive. Health. 6(2): 12891295. doi:10.22038/JMRH.2018.10483.

Jitowiyono S, Kristiyanasari W (2010). Asuhan Keperawatan Post Operasi dengan Pendekatan, NIC, NOC. Nuha Medica Yogyakarta.

Khadijah S, Santoso I, Qana'ah S (2016). Faktor-Faktor Yang Berhubungan Dengan Kejadian Ketuban Pecah Dini Di RSUD Dr. H. Moch Ansari Saleh Banjarmasin 2015, Jurnal Dinamika 
Kesehatan, 7(1). ISSN: 2086-3454, eISSN: 2548-4056,

Kominiarek MA, Gay F, Peacock N.Matern Child Health J (2015). Obesity in Pregnancy: A Qualitative Approach to Inform an Intervention for Patients and Providers, Matern Child Health Journal Aug; 19(8): 1698-712. doi: 10.1007/s10995-015-1684-3.

Maita L (2012). Faktor Ibu yang Mempengaruhi Persalinan Prematur di RSUD Arifin Achmad Pekanbaru, Jurnal Kesehatan Komunitas, 2(1).

Manuaba IAC, Manuaba IBGF, Manuaba IBG (2009). Patologi Obstetri Untuk Mahasiswa Kebidanan, Jakarta, EGC.

Manuaba IBG (2004). Penuntun Kepaniteraan Klinik Obstetri dan Ginekologi, Jakarta, EGC.
Mitayani (2009). Asuhan Keperawatan Maternitas. Salemba Medika Jakarta.

Maryunani A (2009). Asuhan Kegawatan Dan Penyulit Pada Neonatus. Jakarta: Trans Info Medika.

Mohan K, Mishra PC, Singh DK (2013). Clinical Profile of Birth Asphyxia In Newborn, International Journal of Science \& Technology, 3(1). ISSN (online): 250-141X.

Momeni M, Danaei M, Kermani AJ, Bakhshandeh M, Foroodnia S, Mahmoudabadi Z, Amirzadeh R, Safizadeh H, 2017, Prevalence and Risk Factors of Low Birth Weight in the Southeast of Iran, International Journal of Preventive Medicine, doi:10.4103/ijpvm.IJPVM_112_16. 